\title{
Critical Thinking and Iranian EFL Students' Listening Comprehension
}

\author{
Mohsen Zare \\ English Department, Abadeh Branch, Islamic Azad University, PO Box 73979-55956, \\ Abadeh, Iran \\ Tel: 98-917-702-8308Ｅ-mail: zare.mohsen61@gmail.com
}

Fatemeh Behjat

English Department, Abadeh Branch, Islamic Azad University, PO Box 73979-55956,

Abadeh, Iran

Tel: 98-917-313-3393Ｅ-mail: fb_304@yahoo.com

Seyyed Jamal Abdollrahimzadeh

English Department, Abadeh Branch, Islamic Azad University, PO Box 73979-55956, Abadeh, Iran

Tel: 98-917-314-5922Ｅ-mail: sjaamir@yahoo.com

Mehri Izadi (Corresponding author)

Department of English Language, Amin Institute of Higher Education

PO Box 84915-637, Isfahan, Iran

Tel: 98-913-234-0372Ｅ-mail: izadimi@yahoo.com

Received: September 8, 2013 Accepted: Sep. 24, 2013 Published: December 8, 2013 doi:10.5296/ijl.v5i6.4253ＵRL: http://dx.doi.org/10.5296/ijl.v5i6.4253

\section{Abstract}

Shifting to a learner-oriented learning, higher education strives to make learners more 


\section{Macrothink}

International Journal of Linguistics

ISSN 1948-5425

2013, Vol. 5, No. 6

competent in learning process. As such, critical thinking is one of the significant concepts which can optimize learners' directing and controlling learning. The present study aimed at exploring the possible bond between learners' way of critical reasoning and their listening communication. Critical thinking scale and Interchange/Passage Objective Placement Test were administrated among seventy eight senior EFL learners. Pearson correlation and independent sample $t$-test were applied to analyze data. The findings denoted the meditating role of critical thinking, analyzing and reflecting, to indicate listening comprehension and interpret interlocutor's speech and communicate his intention. Results argued that there is a considerable implication to enhance language performances and learning based on critical thinking.

Keywords: Critical thinking, Learners' attainment, Listening performance 


\section{Introduction}

According to critical thinker theorists, critical thinking is a prominent way through which teachers can let learners decide, devise and employ their potential ability. Critical thinkers are able to implement the process of logical thinking to confirm and disconfirm hypothesis, to discern what is true, what is false and separate facts from opinions (Wood, 2002). It leads learners to think logically, manipulate proof and accordingly open previously hidden views for them. As a result, critical construct has received chief attention in SLA area. Defining it, Dewey (1933) refers to critical thinking as "active, persistent, and careful consideration of any belief or supposed form of knowledge in the light of the grounds that support it and the further conclusions to which it tends" (p. 118). Likewise, Chafee (1988) states that critical thinkers put their efforts purposefully and explore the world carefully to clarify and optimize their perception. According to Lai (2011), critical thinking is in association with ability, disposition and background knowledge. With reference to ability, Lai (2011) states that critical thinkers are able to analyze argument, evaluate and make decision (Ennis, 1985; Facione, 1990; Halpern, 1997, cited in Lai, 2011). Critical thinking dispositions cover broad-mindedness, fairness and flexibility (Bailin, Case, Coombs \& Daniels, 1999; Facione, 1990, cited in Lai, 2011). In accord with Lai (2011), background knowledge is one of the essential factors in helping one to think critically. This domain knowledge is at the core of reasonable judgments. Theoretically speaking, this cognitive ability is one of several skills necessary to benefit both teachers and learners toward a better education system. By teaching how to better judge, use inductive/deductive reasoning and solve problems, teachers can assist students in improving their skills and strategies which ultimately result in their achievements.

Considering the aforementioned theories, critical learners adopt reasons, analyze, create association and judge data which ultimately enable them to infer unambiguously. Critical thinking ability can help learners to acquire, store and transform new information and skills effectively. Hence, this cognitive ability has received increasing attention in research over the past two decades. De Boo (1999) and Gardner and Jewler (2000) pointed out that critical learners are successful in problem-solving activities. Similarly, Villavicencio (2011), studied critical thinking in relation to achievements, reported that critical thinking significantly positively correlate with learners' proficiency. In one study, Kamali and Fahim (2011) reported a significant relationship between critical thinking and reading abilities of learners. According to them, critical thinking construct is a strong predicator of learners' achievements.

From a psychological point of view, the role of thinking and reasoning critically is unquestionable. From a cognitive point of view, the role of listening in language education is undeniable. Of four skills, listening is the most difficult and frequently one used. Listening takes an important part in our daily communication. It makes a significant contribution in second/foreign language learning. Nunan (1998) asserted that, "listening is the basic skill in language learning ... in fact over $50 \%$ of the time that students spend functioning in a foreign language will be devoted to listening" (p. 1). Despite of its undeniable role, listening has often been left out and considered as passive skill (Oxford, 1993; Elkhafaifi, 2005). Nevertheless, during the last decades, L2/FL teachers and researchers' attention has shifted 
toward listening, and many acknowledged its importance in language acquisition and research (Oxford, 1993; Richards \& Renandya, 2002). According to Richards and Renandya (2002), listening is a complex stressful process in which interlocutors have less opportunity to go back over the previous input. Fast speech rate, accent, complicated syntactic structure, limited vocabulary knowledge, lack of self-confidence and cultural knowledge are among factors that hinder proper listening comprehension.

According to Galvine and Terrell (2001), listening "is an active process that includes receiving, interpreting, evaluating and responding to a message. It takes effort and concentration" (p. 110). It is the process of receiving, creating meaning from, and responding to input. It contains the ability to recollect information, as well as utilize them to communicate. In other words, it involves construction, retention and reaction to meanings we receive. In so doing, it interrelates attention, awareness, working memory, our schemata and setting context. Evidently, listening process and effective listening comprehension are easily interfered by linguistics and extra-linguistics phenomenon. Therefore, listeners need to be tuned in so that they overcome listening comprehension inefficiency. Concerning listening improvement, Kamali and Fahim (2011) asserted that listening and critical thinking go hand in hand. It is necessary that listeners are able to analyze the speakers and the setting to critically judge the interlocutor's intention. What is worth mentioning is that by developing learners' ability in critical evaluation, it seems we may advance their listening skill.

Concerning self-determination theory, Baleghizadeh and Rahimi (2011) studied the relationship among metacognitive strategy use, motivation and listening test performance of EFL university students. Based on the study, there is a significant relation between listening performance and metacognitive strategy use. They later argued, "using metacognitive listening strategies improves the listening performance of the students, so metacognitive knowledge is linked to the listening ability" (p. 66). Moreover, the study showed that intrinsic motivation is a significant contributor to listening performance and achievements. With regard to listening and personality, Nourmohammadi and Izadi (2011) investigated the relationship between self-efficacy and listening strategies. According to Nourmohammadi and Izadi, self-beliefs play a significant role in learners' performance and selection of strategies. In another study, Rebuck (2008) showed that authentic listening is motivational and increase learners' interest and their perception in listening. Generally speaking, studies indicate that personal characteristics play an important role in learning process (Dewey, 1993; Pajares, 2003). Compared with other students, high critical thinker performs critically in learning. To make it simple, critical learners are more active in their learning, and particularly listening in this context.

To be an effective listener, it is necessary that learners carefully analyze the speaker's intention and consider communication setting. In order to analyze the intention of the speaker, listeners should evaluate the illocutionary force of speaker's message, consider the supporting materials provided by the speaker, and contemplate to what extent he can trust speaker. Similarly, analyzing the communication context makes it necessary that learners judge what plays a role in comprehension and what does not, and how the setting works on understanding. As it seems, contemplating, asking question, inferring and reasoning are 
among key factors which improve listening skill in L2. As referred by Kamali and Fahim (2011), comprehension skills can effectively be improved through increasing learners' critical skill. The more important critical thinking is, the less it is studied in L2 area. More importantly, listening is one part of the L2 learning in which nearly most of L2 learners face and have problems. It is also one of the fundamental means of communication. Without listening, learners cannot effectively express themselves and receive attentions from speakers that is effective communication. It is also regrettable that such an important issue has been specified a small portion. To this end, in the present study we aim to investigate the probable relation between such an effective cognitive ability and fundamental listening skill.

Unfortunately, critical thinking in listening in an EFL context especially in Iran has not been investigated utterly. Accordingly, the present study explores the relationship between critical thinking and listening performance to indicate the extent to which critical thinking has relationship with learners' listening proficiency. Furthermore, this research study differences between high critical thinkers and their low counterparts on their listening performance. In this regard, exploring learners' critical ability will enlighten their performance in listening skill which ultimately results in their improvement.

\section{Method}

To find answers to the research questions, a questionnaire and a test were employed. Accordingly, the study adopted a quantitative method of analyzing the variables of the study. The study is a correlational one which attempts to clarify the degree of overlapping between learners' critical thinking and their performances in listening. In an objective approach applying statistical analysis, the study provides a concrete report of students' performances.

\subsection{Participants}

In order to conduct the study, 78 senior students from Amin Institute of Higher Education participated in the study. Forty students study English Language Teaching and thirty eight students study Translation Studies. They mostly age from 21 to 25 . The students have studied English Language at least 3 years at the university.

\subsection{Instruments}

To study learners' critical thinking beliefs, a Critical Thinking questionnaire adapted from Naieni (2005) was employed. The scale was originally developed by Peter Honey (2000). The present questionnaire was improved and suited for Iranian EFL learners. Moreover, the reliability of the scale was reported a high consistency 0.86 (Naieni, 2005). The questionnaire consists of 30 items using a 5-point Likert scale. Students were asked to read items and select an option ranging from never to always in terms of their critical thinking beliefs.

Moreover, delving students' listening performances, the study adopted Interchange Objective Placement Test designed by Lesley, Hansen and Zukowski-Faust (2005). The test includes 70 multiple-choice items which primarily assess learners' receptive skills (listening, reading, and grammar). The test consists of three sections: Listening (20 items), Reading (20 items), and Language Use (30 items). 20 items of listening were applied in this study. The listening items 
evaluate students' ability to learn main idea, context, and supporting information in a conversation, as well as the interlocutors' intention. According to Lesley, Hansen and Zukowski-Faust (2005, p. 5), "the different components of the test may be administered to individuals or to groups, and in any order". Collecting data, students were asked to listen to audio tracks and selected the option that they thought it was the correct one. Following that, questionnaire and test were collected to analyze data.

\section{Result and Discussion}

Descriptive statistics were first obtained for learners' critical thinking and their listening attainment. Table 1 depicts results of descriptive statistics of critical thinking skills and listening performances. The analysis of critical thinking questionnaire revealed the mean score of $\mathrm{M}=99.97$ denoting that Iranian learners apply logical reasoning and try to learn clearly and knowledgably. Likewise, learners perform fairly well $(M=14.38)$ in their listening test which indicated that they can attend to speakers' attention.

Table 1. Descriptive Statistics of Critical Thinking and Listening Performance

\begin{tabular}{|l|r|r|r|r|r|}
\hline & \multicolumn{1}{|c|}{ N } & Minimum & Maximum & \multicolumn{1}{c|}{ Mean } & \multicolumn{1}{c|}{ Std. Deviation } \\
\hline Critical Thinking & 78 & 70.00 & 126.00 & 99.97 & 11.77 \\
\hline Listening & 78 & 7.00 & 20.00 & 14.38 & 3.51 \\
\hline Valid N (listwise) & 78 & & & & \\
\hline
\end{tabular}

To test the possible correlation between learners' critical thinking skill and their listening performance, Pearson product correlation was employed. The results of analysis highlight a significant correlation between variables $(\mathrm{r}=0.86)$ at $p=0.00$ level of significance. That $\mathrm{r}=0.86$ association indicates that learners highly apply their reasoning and inferring to understand interlocutors' speech. Table 2 also reveals that the correlation is positive $(r=0.86)$. Put it simple, as learners' employ purposeful thinking, responsibility in learning and question the credibility of information, they listen and understand more effectively.

Table 2. Pearson Correlation between Critical Thinking and Listening Performances

\begin{tabular}{|l|l|r|r|}
\hline \multicolumn{2}{|c|}{} & \multicolumn{1}{c|}{$\begin{array}{c}\text { Critical } \\
\text { Thinking }\end{array}$} & Listening \\
\hline \multirow{2}{*}{$\begin{array}{l}\text { Critical } \\
\text { Thinking }\end{array}$} & Pearson Correlation & 1 & .860 \\
\cline { 2 - 4 } & Sig. (2-tailed) & 78 & .000 \\
\cline { 2 - 4 } & $\mathrm{N}$ & .860 & 78 \\
\hline \multirow{3}{*}{ Listening } & Pearson Correlation & .000 & 1 \\
\cline { 2 - 4 } & Sig. (2-tailed) & 78 & 78 \\
\cline { 2 - 4 } & $\mathrm{N}$ & & \\
\end{tabular}

**. Correlation is significant at the 0.01 level (2-tailed).

The present study is in line with other studies (Kamali \& Fahim, 2011; Villavicencio, 2011; Baleghizadeh \& Rahimi, 2011). Kamali and Fahim (2011) similarly reported a significant relationship between critical thinking and reading abilities of learners $(p=.000<.05)$. Halpern (2003) stated that critical thinking "increase[s] the probability of a desirable outcome, ... the kind of thinking involved in solving problems, formulating inferences, calculating likelihoods, and making decisions" (p. 6). The findings supported Facione's (2007) 
study that there is a significant correlation between critical thinking and reading comprehension, "improvements in the one are paralleled by improvements in the other" (p. $18)$.

Based on the second objective of the study, independent sample $t$-test was applied to check whether learners with higher critical thinking were more successful in their listening performances than low ones, or there are no significant differences between them. To begin with, learners were divided to two groups of high and low critical thinkers based on the mean of critical thinking (see Table 1). The cut point was indicated according to average of minimum (70.00) and maximum (126.00) scores of the students in the questionnaire. Based on learners' mean score, 98 mean score was selected as the cut point to divide learners to two groups. Out of 78 learners, forty seven students belonged to the first group, i.e. high, and the rest of students, thirty one, entered the second or low critical thinkers group. To statistically prove that the division is correct and students in high group are really high and the ones in low are actually low, an independent sample $t$-test was run.

Table 3. Independent Sample t-Test between High and Low Critical Thinkers

\begin{tabular}{|l|l|l|l|l|l|l|l|l|}
\hline & & $\mathrm{F}$ & Sig. & $\mathrm{t}$ & $\mathrm{df}$ & $\begin{array}{l}\text { Sig. } \\
(2 \text {-tailed) }\end{array}$ & $\begin{array}{l}\text { Mean } \\
\text { Difference }\end{array}$ & $\begin{array}{l}\text { Std. Error } \\
\text { Difference }\end{array}$ \\
\hline $\begin{array}{l}\text { Critical } \\
\text { Thinking } \\
\text { Level }\end{array}$ & $\begin{array}{l}\text { Equal } \\
\text { variances } \\
\text { assumed } \\
\text { Equal } \\
\text { variances } \\
\text { not } \\
\text { assumed }\end{array}$ & 2.619 & .110 & 11.043 & 76 & .000 & 18.75909 & 1.69868 \\
\cline { 2 - 8 } & & & 10.466 & 52.681 & .000 & 18.75909 & 1.79242 \\
\hline
\end{tabular}

As Table 3 revealed there is statistical differences between high and low critical thinkers $(p=0.00)$. It denotes that learners in group 1, i.e. high, outperform in applying logical reasoning and considering different aspects compared to their counterparts in group 2, i. e. low, inasmuch as they justify and question less than high critical thinkers $(\mathrm{t}=11.04)$. Following meaningful differences between high and low critical thinkers, the significant of differences between high and low groups with regard to their listening performance were calculated. The analysis was based on independent sample $t$-test.

Table 4. Independent Sample t-Test between High and Low Critical Thinkers and their Listening Performance

\begin{tabular}{|l|l|r|r|r|r|r|}
\hline \multicolumn{2}{|c|}{} & $\mathrm{F}$ & Sig. & $\mathrm{t}$ & $\mathrm{df}$ & $\begin{array}{c}\text { Sig. } \\
\text { (2-tailed) }\end{array}$ \\
\hline Listening & \begin{tabular}{l} 
Equal variances \\
assumed \\
Equal variances \\
\cline { 3 - 6 }
\end{tabular} & .110 & .741 & 8.678 & 76 & .000 \\
\cline { 3 - 6 } & & & 8.704 & 65.027 & .000 \\
\hline
\end{tabular}

According to Table 4, there are significant differences between learners' level of critical 
thinking and their listening performances. Higher critical thinkers significantly understand better the receptive input than low critical thinkers $(p=0.00)$. The $t$-test table reveals that high critical thinkers follow deep thinking and reasoning for further perception. Moreover, they make value judgments and deduce message. They actively apply critical thinking skill to deal with obstacles facing their communication. Similarly, Kamali and Fahim (2011) reported that high critical thinkers $(\mathrm{M}=14.61)$ perform better in face of reading tasks as oppose to their low counterparts $(M=9.91)$. Moreover, $t$-test table revealed significant differences between groups with regard to their reading performances $(\mathrm{p}=0.00)$. The cognitive skills of synthesis, assessment, implication, and monitoring used in receptive skills (Celce-Murcia, 2001) are those cognitive skills which according to Facione (2007) are central to critical thinking: "as to the cognitive skills, here is what the experts include as being at the very core of critical thinking: interpretation, analysis, evaluation, inference, explanation, and self-regulation" (p. 4).

\section{Conclusion}

The primary underlying concern of the present study was how applying logical thinking could best help students develop their language performances. The aim of this study was to examine the bond between learners' critical thinking and their listening performances. Moreover, it was assessed how high critical thinkers perform to low critical learners concerning listening tasks. Critical thinking scale and listening test were administrated, and the data were collected for further analysis. It was indicted that there is a significant high correlation between learners' logical consideration and their perception of listening input. The findings also revealed that high critical thinkers significantly outperformed low critical learners. Finding practical and significant results highlighted that critical thinking skill provides a powerful incentive to integrate this construct more widely into educational curricula.

It is implied that developing a positive critical thinking belief can strengthen learners' confidence to listen and call the task into challenge. From the viewpoints of instructors, promoting learners' critical thinking abilities as "analyzing complex issues and situations and generating solutions, making connections and transferring insights to new contexts, and developing standards for decision making" (Reed, 1998, p. 162), are requirements in order to be successful. It is worth mentioning that learners' ability to deduce and analyze help them to consider the supporting materials provided by the speaker and analyze the setting. Accordingly, syllabus designers and materials developers should consider critical thinking as one of the effective primes in students' academic and future career accomplishment.

The results of the study suggest that the students are experimentally studied in order to see how they perform in their listening tasks in an experimental research. It is suggested that other researchers explore the effect of critical thinking in relation to other skills of writing and speaking to add to the significance of reasoning and deducing to learners' language performances and developments. Analyzing critical thinking in accord with psychological constructs as self-efficacy and self-regulation can be illuminating and they can explain how these constructs are connected in order to develop students' performances. 


\section{$\Lambda$ Macrothink}

\section{References}

Bailin, S., Case, R., Coombs, J. R., \& Daniels, L. B. (1999). Conceptualizing critical thinking. Journal of Curriculum Studies, 31(3), 285-302.

Baleghizadeh, S., \& Rahimi, A. H. (2011). The relationship among listening performance, metacognitive strategy use and motivation from a self-determination theory perspective. Theory and Practice in Language Studies, 1(1), 61-67.

Celce-Murcia, M. (2001). Teaching English as a second or foreign language (3rd ed.). MA: Heinle \& Heinle.

Chaffee, J. (1988). Thinking critically. Boston: Houghton Mifflin.

De Boo, M. (1999). Enquiring children, challenging teaching. Buckingham: Open University Press.

Dewey, J. (1933). How we think: A restatement of the relation of reflective thinking to the educative process. Boston: D.C. Heath.

Elkhafaifi, H. (2005). The effect of pre-listening activities on listening comprehension in Arabic learners. Foreign Language Annals, 38(4), 505-513.

Ennis, R. H. (1985). A logical basis for measuring critical thinking skills. Educational Leadership, 43(2), 44-48.

Facione, P. A. (1990). Critical thinking: A statement of expert consensus for purposes of educational assessment and instruction. Millbrae, CA: The California Academic Press.

Facione, P. A. (2007). Critical thinking: What it is and why it counts. [Online] Available: http://insightassessment.com/t.html (October 5, 2012)

Galvin, K. M., \& Terrell, J. (2001). Communication works. USA: National Textbook Company.

Gardner, J. N., \& Jewler, A. J. (2000). Your college experience: strategies for success (4th ed.). Belmont: Wadsworth.

Halpern, D. (1997). Critical thinking across curriculum: A brief edition of thought and knowledge. Mahwah, NJ: Lawrence Erlbaum.

Halpern, D. (2003). Thought and knowledge: An introduction to critical thinking. Mahwah, NJ: Erlbaum.

Honey P. (2000). Critical thinking questionnaire. [Online] Available: http://www.PeterHoney.com (October 5, 2007)

Kamali, Z., \& Fahim, M. (2011).The relationship between critical thinking ability of Iranian EFL learners and their resilience level facing unfamiliar vocabulary items in reading. Journal of Language Teaching and Research, 2(1), 104-111. http://dx.doi.org/10.4304/jltr.2.1.104-111 


\section{Macrothink}

International Journal of Linguistics

ISSN 1948-5425

2013, Vol. 5, No. 6

Lai, E. R. (2011). Critical thinking: A literature review (research report). [Online] Available: http://www.pearsonassessments.com/research (April 12, 2013).

Lesley, T., Hansen, C., \& Zukowski-Faust, J. (2005). Interchange passages: Placement and evaluation package. Cambridge: Cambridge University Press.

Naeini, J. (2005). The effects of collaborative learning on critical thinking of Iranian EFL learners. Unpublished M.A. Thesis, Islamic Azad University, Central branch, Tehran, Iran.

Noormohammadi, E., \& Izadi, M. (2011). The relationship between listening self-efficacy beliefs of Iranian EFL students and their use of listening strategies. Ferdowsi Review, 2(4), 59-71.

Nunan, D. (1998). Approaches to teaching listening in the language classroom. In Proceedings of the 1997 Korea TESOL Conference. Korea TESOL, Taejeon, Korea.

Oxford, R. (1993). Research update on L2 listening. System, 21(2), 205-211. http://dx.doi.org/10.1016/0346-251X(93)90042F

Pajares, F. (2003). Self-efficacy beliefs, motivation, and achievement in writing: A review of the literature. Reading and Writing Quarterly, 19, 139-158.

Rebuck, M. (2008). The Effect of excessively difficult listening lessons on motivation and the influence of authentic listening as a "lesson-selling" tag. JALT Journal, 30(2), 197-222.

Reed, J. H. (1998). Effect of a model for critical thinking on student achievement in primary source document analysis and interpretation, argumentative reasoning, critical thinking disposition, and history content in a community college history course. Unpublished PhD Thesis, University of South Florida.

Richards, J. C., \& Renandya, W. A. (2002). Methodology in language teaching: An anthology of current practice. Cambridge University Press, New York. http://dx.doi.org/10.1353/jhe.2002.0056

Villavicencio, F. T. (2011). Critical thinking, negative academic emotions, and achievement: A meditational analysis. The Asia-Pacific Education Researcher, 20(1), 118-126.

Wood, R. (2002). Critical thinking. [Online] Available: www.robinwood.com/Democracy/GeneralEssays (July 5, 2013) 